\title{
TO BE PART OF... ARCHITECTURE, DECORATION OR ICONOGRAPHY. DOCUMENTING AZULEJO AS INTEGRATED HERITAGE
}

\author{
R. S. Carvalho ${ }^{1}$ \\ ${ }^{1}$ Rede de Investigação em Azulejo, ARTIS - Instituto de História da Arte, Faculdade de Letras, Universidade de Lisboa, Portugal - \\ rscarvalho@letras.ulisboa.pt
}

Commission II, WG II/8

KEY WORDS: Integrated Heritage, Data Structure, Documentation, Art History, Digital Art History, Indexation, Azulejo

\begin{abstract}
:
Az Infinitum - Azulejo Referencing and Indexation System may be briefly defined as a work tool combining Art History's traditional methods with the use of digital technologies, in order to create a system designed to document, catalogue and index all the tile decorations produced and applied in Portugal since the late $15^{\text {th }}$ century and still found in their original locations. By highlighting the potentialities of $\mathrm{Az}$ Infinitum and by describing its data structure and the procedures used to collect and upload information, the present article proposes a reassessment of the project in light of these parameters, as well as a discussion of future developments. Moreover, it aims to clarify the link between the norms followed within the system and the ones used internationally. This link reflects the aim of integrating the system within previously developed structures, without losing sight of the specificities of a hybrid form of heritage, whose documentation must be adapted in different ways. Such a need has led to the development of specific data structures, designed to meet the unique characteristics of patterned tile decorations.
\end{abstract}

\section{INTRODUCTION}

The main purpose of this article is to introduce the ongoing research-oriented project Az Infinitum - Azulejo Referencing and Indexation System (figure 1), and to discuss its methodologies concerning the documentation of a specific form of heritage: Portuguese tile decorations still found in situ.

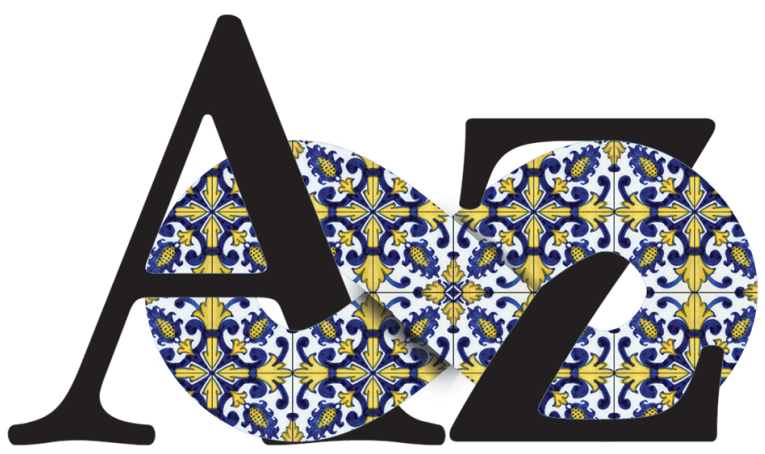

Figure 1. Logo of Az Infinitum, by Duarte Lázaro (2012), with the pattern P-17-00101

Az Infinitum was launched in 2010 and made available online in 2012, in open access (http://redeazulejo.letras.ulisboa.pt/pesquisa-az). After seven years of activity, in collaboration with other institutions and researchers, the time has come to take stock of the results and to lay the groundwork for future developments. If, on the one hand, the project is interested in increasing the number of partners using $A z$ Infinitum as a tool for documenting, researching and getting to know the history of tile decorations, it also aim, on the other hand, to start a wider debate, ideally at an international level, about the relevance of the methods used to assess the results that have hitherto been reached. Moreover, the coordinators plan to integrate the project within wider documentation networks, capable of promoting a more interdisciplinary approach, especially in what regards the use of digital technologies.

Accordingly, this text begins with a brief contextualizing note on the importance of tile decorations in a country like Portugal, and on the meaning of the term "integrated heritage", meant to clarify the extent to which the azulejo falls under this category and the related emergence of hybrid documentation models. This note is followed by a brief characterization of Az Infinitum and a discussion of the documentation and data structuring methods employed by this information system, based in a relational database. While the basic description of the system's aims and functions, which is necessary to contextualize the issue, can be found in other texts, this article focuses on the debate about its underlying data structure, derived from internationally accepted norms. The conclusion outlines some of the future directions the project aim to follow.

\section{THE $A Z U L E J O$ AS INTEGRATED HERITAGE}

In Portugal, the azulejo is a very important and iconic heritage, rightly considered one of the country's most distinctive art forms. However, its unique features can only be fully appreciated when tile coverings are kept in the locations for which they were originally conceived, in dialogue with the surrounding architecture and with other art forms. They are the architecture's outer "skin", as it were - but one capable of transforming the way we experience the different spaces. The azulejo is an active form of covering, which loses its meaning once it is taken out of context. It falls, therefore, under the category of integrated heritage - or, according to theoretical conventions, "destination-bound" heritage (Calado, Leite e Pereira, 2003: 5-8) — and this designation determines the way in which it is documented.

The term integrated heritage designates the (theoretically) undivided unity formed by a given building and its composing assets (figure 2.). This concept was introduced by the Venice 
Charter (1964, art. 8), and granted a wider scope by the Convention for the Safeguard of Architectural Heritage, signed in Granada in 1985 (Art. 1, 1). It was acknowledged in Portugal in 1997, with the creation of the Portuguese Institute for Architectural Heritage (Instituto Português do Património Arquitectónico), which recognized the concept's importance and its own responsibility in safeguarding the country's cultural heritage, including its movable and immovable assets (1).

The main difference between the system we will describe below and other projects concerning heritage documentation in general, and the azulejo in particular (2), lies precisely in this conception of tile decorations as an integrated form of heritage - a part of the architecture, the decoration and the iconographic programme of a given space.

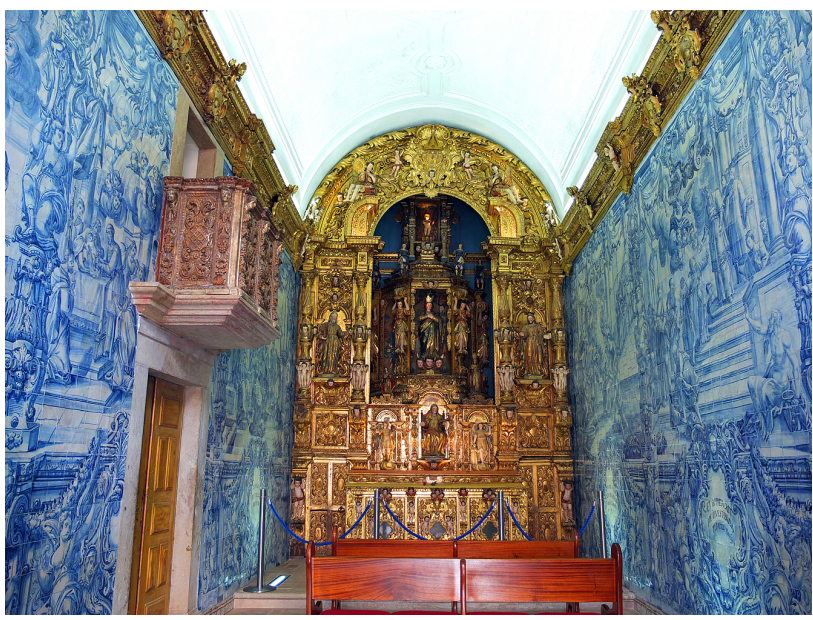

Figure 2. Loulé, Chapel of Our Lady of Conceição, second quarter of the $18^{\text {th }}$ century. Photo by Jorge Guerra Maio

Many existing projects focus on the development of information systems applied to cultural heritage, in the fields of conservation, digital photography, or $3 \mathrm{D}$ reconstruction and cataloguing, among others (3). The aim of the present article,

(1) Diário da República n. ${ }^{\circ}$ 113/1997, Série I-A de 1997-05-16, Decreto-Lei n. ${ }^{\circ}$ 120/97, pp. 2421-2433.

(2) Consider, for example, the Portuguese project Digitile (http://digitile.gulbenkian.pt/), which simply makes available different sources and studies about tile decorations and ceramics, or the Spanish projects Ataifor, Augusta and Pisano, joined together in the platform Retablo Cerámico (http://www.retabloceramico.net/noticias.htm). Note that in these cases the data structures are very outdated and do not even allow the user to cross-check information. The institute Promoción Cerámica (Castellón - España) did play an important role by promoting, until 2014, the creation of photographic records and catalogues of architectural ceramics in the Iberian Peninsula. But the results of these efforts were not duly disseminated.

(3) Consider, for example, the proceedings of the $26^{\text {th }}$ International CIPA Symposium - Digital Workflows for Heritage Conservation, published in volume IV-2/W2 of the ISPRS Annals of the Photogrammetry, Remote Sensing and Spatial Information Sciences, in 2017. As an example of projects that develop databases taking into account issues related to integrated heritage, it is worth highlighting the Continent allegories in the Baroque age - a research database (http://continentallegories.univie.ac.at), which resorts to Iconclass in order to classify the different representations. This project is part of the Research Group for Baroque Ceiling however, is not to provide an overview of the existing literature on a subject that is already extremely wide, but simply to highlight the $A z$ Infinitum's uniqueness as a documentation system for integrated heritage, which also includes a specific tool for cataloguing tile patterns. Indeed, the current lack of interest in integrated heritage is clearly shown by the fact that international heritage documentation norms only refer to movable and immovable heritage, and must be adapted in order to be applied to what we consider to be integrated heritage.

\section{THE $A Z$ INFINITUM - AZULEJO REFERENCING AND INDEXATION SYSTEM}

Az Infinitum may be briefly defined as a work tool combining Art History's traditional methods with the use of digital technologies, in order to create a system designed to document, catalogue and index all the tile decorations produced and applied in Portugal since the late $15^{\text {th }}$ century and still found in their original locations. The storage, use and dissemination of data are shared with all other projects and documentation procedures.

Its main goals include referencing and cataloguing azulejos produced or applied in Portugal; studying them; contributing to their preservation by promoting a heritage policy based on the actual knowledge of these works; disseminating this knowledge, with a view to alerting local communities to the importance of preserving this vast heritage.

The project was born out of specific research questions, raised by a team of art historians from various institutions, as well as computer engineers and graphic designers (4), all of whom wished to "create a system capable of documenting tile decorations from all periods and styles still found in situ, and to set up a wide-ranging dialogue between concepts like space, time, artistic agents, iconography, techniques, or materials. The aim was to generate contextualized readings covering long periods of time, thereby enabling researchers to zoom in and out on a history of more than five centuries, which is by no means linear, but multidimensional" (Carvalho, 2018).

Presently, in its visible component, Az Infinitum allows for five different ways of entering the system, corresponding to the main areas defined at the outset (figure 3): 1) in situ; 2) iconography; 3) patterns and frames; 4) authorships; 5) bibliography. Even though the first of these domains coordinates all the others, the system's relational structure enables users to access the data from any entry point.

The in situ section contains a register of the coverings still found on location (either in their original site or reapplied elsewhere) and offers information on the corresponding

Painting in Central Europe (BCPCE)

(https://bcpce.hypotheses.org/). The Arches, developed by the Getty Conservation Institute and the World Monuments Fund (https://www.archesproject.org/) is another extremely valuable example of "an open source software platform freely available" to inventory and manage immovable cultural heritage, based on international standards. One of the future aims we plan to fulfil is precisely to clarify the extent to which $A z$ Infinitum may use the Arches.

(4) Az Infinitum is developed by the Rede de Investigação em Azulejo (Azulejo Research Network), from the School of Arts and Humanities, University of Lisbon, in partnership with the National Azulejo Museum and the company Sistemas do Futuro. 
buildings, the tiled spaces (5) and the coverings themselves, according to a hierarchical structure moving from the most general to the most specific and privileging the notion of azulejo as integrated heritage.

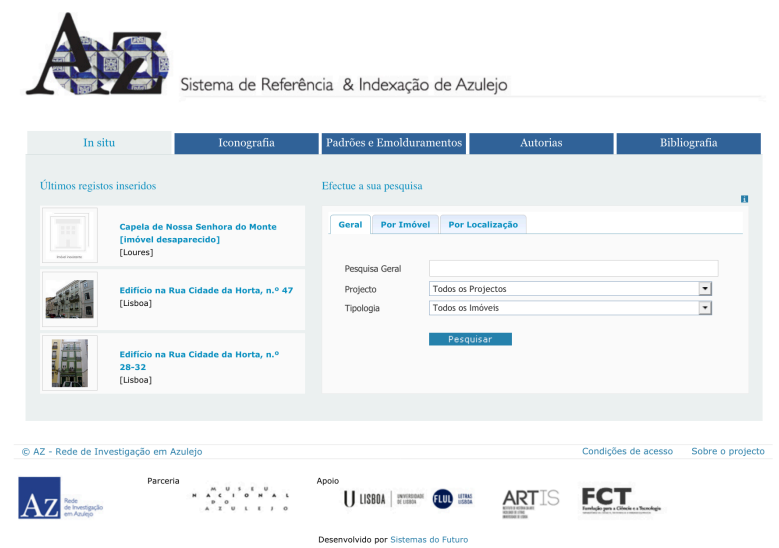

Figure 3. Homepage of Az Infinitum - Azulejo Referencing and Indexation System

The iconography refers to the inventory of the themes and specific aspects depicted in the azulejos, carried out with the aid of Iconclass, a referencing system applied to cultural data (www.iconclass.org). One of Az Infinitum's most important elements, due to the complexity of the projects associated with it, is the domain of patterns and frames, based on a specific terminology for cataloguing tile frames. This aspect will be discussed in detail below. The authorships section offers a comprehensive list of the different agents involved in each work - potters, potteries, tilers, painters, artists, architects and factories, among others - complete with biographical notes and detailed chronologies. The latter enable the crossreferencing of data, revealing personal and professional relationships that are crucial for a global, non-artistic approach to these works. Finally, the bibliography offers a vast and updated catalogue of books (with analytic data) and articles on Portuguese tile decorations, many of which with commentaries.

Aware, from the very beginning, of the almost infinite nature of the task the team was taking on - namely the thorough inventory and documentation of Portugal's tile heritage - as well as of the practical, and hence financial difficulties involved in this kind of work, the team chose to divide the main project into different subprojects, with a more limited scope, which can either be taken over by the Az Infinitum team or arise from the collaboration with external entities. At the same time, by allowing $A z$ Infinitum to be used by other institutions and researchers, as a work tool for processing information in connection with Master's theses, PhD theses and other studies, the project have ensured that the system is permanently updated.

However, Az Infinitum also aspires to become a community capable of sharing work methodologies, in a collaborative sense. The system may be understood, in its current phase, as a means of compiling data with various origins and formats, in order to turn it into relevant information, and thereby to improve the knowledge and the preservation of this heritage. But it is also plan, in the near future, to transform the system into a vast repository of information, focused not only on its original relational database, but also on communicating with

(5) Including, in the general description, a brief mention of the other art forms present. other databases following the same documentation norms (standards).

\section{DOCUMENTATION AND DATA STRUCTURE}

In a wide and open system such as Az Infinitum, normalization is absolutely essential. And this term refers no only to the system's standards, to the data standards (data structure, rules and conventions, terminology) and to the information interchange standards, but also - and above all - to the procedural standards regarding practical heritage documentation, as we will see shortly.

The documentation of tile decorations requires, on the one hand, the use of internationally tested norms, and on the other the acknowledgement of specific rules, which make it necessary to combine data structures pertaining to different kinds of heritage and to develop very specific information groups. Accordingly, the documentation and register procedures were developed alongside the data structure and published in a Guide for the Inventory of Azulejos found in situ (Carvalho et at., 2018) (6), available in PDF format and on a specific website (https://azinfinitum.wixsite.com/guiainv). This was intended to facilitate the changes - or the debate about the changes - that should be introduced periodically, in order to guarantee an actual inventory, cataloguing and documentation practice.

The assumption that the azulejos must be "read" in context, that is, in the spaces in which they are applied, led to the system's first hierarchical structure - cataloguers must register the building, the areas of the building containing ceramic coverings, and only then, on a third level, the coverings themselves. Therefore, the first procedure relates to the context: "Considering the relationship between a tile covering and the architecture on which it is based, and with which it interacts, the organization of the inventory must always take into account the architectural context in which the covering was applied, as well as the other artistic manifestations present therein. In this process, and before initiating the inventory itself, a reading scheme of the building and the corresponding tiled areas must be organized, following a previous survey, in order to facilitate the definition of these elements. The inventory should therefore obey the hierarchical order of the different (interior) spaces with in situ ceramic coverings, organized in the form of a tree, from the most general to the most specific, i.e. building / area / covering" (Carvalho et at., 2018).

This procedure, the key to understanding the system, is not without consequences for its structure, combining different modules for the documentation of movable and integrated heritage, within a relational data model whose data structure is consonant with international norms. We refer, in particular, to the Core Data Index to Historic Buildings and Monuments of the Architectural Heritage and the Core Data Standard for Archaeological Sites and Monuments, used for the description of the buildings and spaces in which the tile covering is found; and also to the International Guidelines for Museum Object Information: the CIDOC Information Categories, as well as to the Categories for the Description of Works of Art (CDWA) and Cataloging Cultural Objects: A Guide to Describing Cultural Works and Their Images (CCO), in what regards tile coverings.

(6) The result of a partnership between the Azulejo Research Network (ARTIS-IHA/FLUL), the National Azulejo Museum and the Architectural Heritage Information System (Sistema de Informação para o Património Arquitectónico (SIPA) / DGPC). 
Although the CIDOC's categories refer to museological or movable items, the main information groups also apply to integrated heritage. This much is made clear by an analysis of the CDWA, which have a wider scope and include both works of art and architecture.

When cataloguing the building and space, that is, when characterizing the context of a given ceramic covering, the information groups and categories deemed essential (core) are not numerous. The project has opted to leave much of this work to other databases with heritage inventories, such as the two national databases managed by the General Directorate for Cultural Heritage (Direção-Geral do Património Cultural DGPC), the organism of the Ministry of Culture in charge of overseeing Portugal's cultural heritage (7). It resorts, above all, to the following information groups: building number, name, building type, description, chronology, names, legal provisions, location, number, cataloguing and related files (with areas of the buildings, integrated heritage, references, etc.).

As regards the integrated heritage, the information groups are the following: description, iconography, techniques, classification, authorships, chronology, locations, materials, measurements, productions, techniques, patterned catalogue. The complexity of tile decorations requires, for example, that information groups such as the state of conservation (condition) be filled by specialized technicians - something which, at least until now, has not taken place, as this characterization, albeit possible and allowed by the system, was not among the project's primary goals.

Currently, in the context of the present effort to discuss and assess the methods that were adopted, the project is putting together a comparative grid featuring the information groups used in Az Infinitum and the corresponding groups mentioned in the various international standards. This grid will be made available on the website of the Guide for the Inventory of Azulejos found in situ. It is also reassessing certain options, such as the rule that determines what a description amounts to, now being analysed in light of the CDWA and the CCO.

So far, following certain national guidelines, this field was used to write an "objective and concise text referring to the space or covering under analysis, and not to the knowledge thereof. It should be organized from the most general to the most specific". However, after a few years of practice and users feedback, the project is considering the possibility of adopting the CDWA's guidelines for descriptive notes: "A textual description of the work, including a discussion of issues related to it. Important information in this note should be indexed in other appropriate categories" (Baca, Harpring, 2016). These guidelines are further developed in the CCO: "The element consists of a descriptive note that is generally a relatively brief essay-like text, detailing the content and context of the work. It is a free-text field used to record comments and an interpretation that may supplement, qualify, or explain information indexed in various other elements. The element should contain a single coherent statement covering some or all of the salient characteristics and historical significance of the work of art or architecture. Topics covered may include a discussion of the subject, function, or significance of the work" (Baca et al., 2006). The relevant information is indexed, so that

(7) SIPA - Architectural Heritage Information System (http://www.monumentos.gov.pt) and the research made available by the DGPC in http://www.patrimoniocultural.gov.pt/pt/patrimonio it can be accessed and studied, but the description is more like a historic-artistic note, meant to contextualize the indexed data and, in a way, to translate it and make it available to all kinds of users. The description corresponds therefore to the first level of a hierarchical mode of access, leading to more complex or structured levels.

Considering once again the specific nature of this heritage, other procedures refer to the way in which one "looks" at applied azulejos. These are above all conventions used to organize the information, conditioning the way it is uploaded in the system: "In indoor spaces, the description of the space must be made from left to right, starting from the entrance. That is to say, the inventory must proceed from wall to wall: when one enters a given space, the first wall is the one to the left and the last one the entrance wall. The covering must be read, vertically, level by level (moving upward), and, horizontally, section by section (from left to right). The sections may be figurative, ornamental or patterned" (Carvalho et al, 2018).

Concerning the use of a controlled vocabulary — and since $A z$ Infinitum is, at least for now, written in Portuguese - the project concern was to maintain a correspondence with international thesauri, even if that meant adapting and translating the original texts. Therefore, and given the importance of figurative decorations, one of the initial tasks was to translate the Iconclass into Portuguese. In this classifying system, applied to cultural contents, the terms and corresponding alphanumeric codes are structured hierarchically, and complemented by keywords (8). The advantage is evident: if the cataloguing is correct, the search results are almost precise. But although this option allows the system's users to interact and collaborate with larger groups of experts, the project has experienced some difficulties in adapting Iconclass to certain forms of Catholic iconography, given the resistance offered to a set of potentially controversial terms. This difficulty has reiterated the need for an accurate knowledge of the sources that are used and adapted, as well as for the openness to change and the introduction of new terms to the main list.

Given the specificity of some of the terms used in the field of azulejo studies, the project has sought to harmonize the terminology employed on a national level by key institutions like the National Azulejo Museum with thesauri such as the Art and Architecture Thesaurus (AAT), from the Getty Research Institute. The different terms have already been mapped out. A similar issue arises with regards to the artists' names, although only a very small number is present in the Union List of Artist Names (ULAN). To solve this, an ongoing project was created, Az.Thesaurus, where these lists and authorities are organized in view of their future contribution to international terminological standards.

Nevertheless, this normalizing effort was still lacking a "catalogue" for identifying and describing different tile patterns, which is why it has decided - building on the pioneering work of another researcher, João Miguel dos Santos Simões (19071972) - to develop a new tool within Az Infinitum, as we will see shortly.

(8) Iconclass was translated into Portuguese between 2012 and 2014, by a working group of the Azulejo Research Network and the National Azulejo Museum. 


\section{THE NEED OF A SPECIFIC DATA STRUCTURE}

Unlike figurative azulejos, with unique (or almost unique) characteristics, designed for a specific location, patterned azulejos and frames are serially produced (manually or industrially) and can be applied anywhere and combined in different ways. Consequently, the study of these decorative elements poses specific challenges to art historians, concerning the exact chronology of their production and application, the identification of their origin and authorship (from the painters to the factories), the recurrence of decorative motifs, and so on.

Patterned azulejos are one of the main axes of Portuguese tilework, along with figurative panels and, to a lesser extent, ornamentation. In more than five centuries of tile application, there were moments when patterns were dominant. However, they usually appear alongside other decorative solutions. Their study has gained ground in recent years, but it continues to be overshadowed by that of figurative tiles.

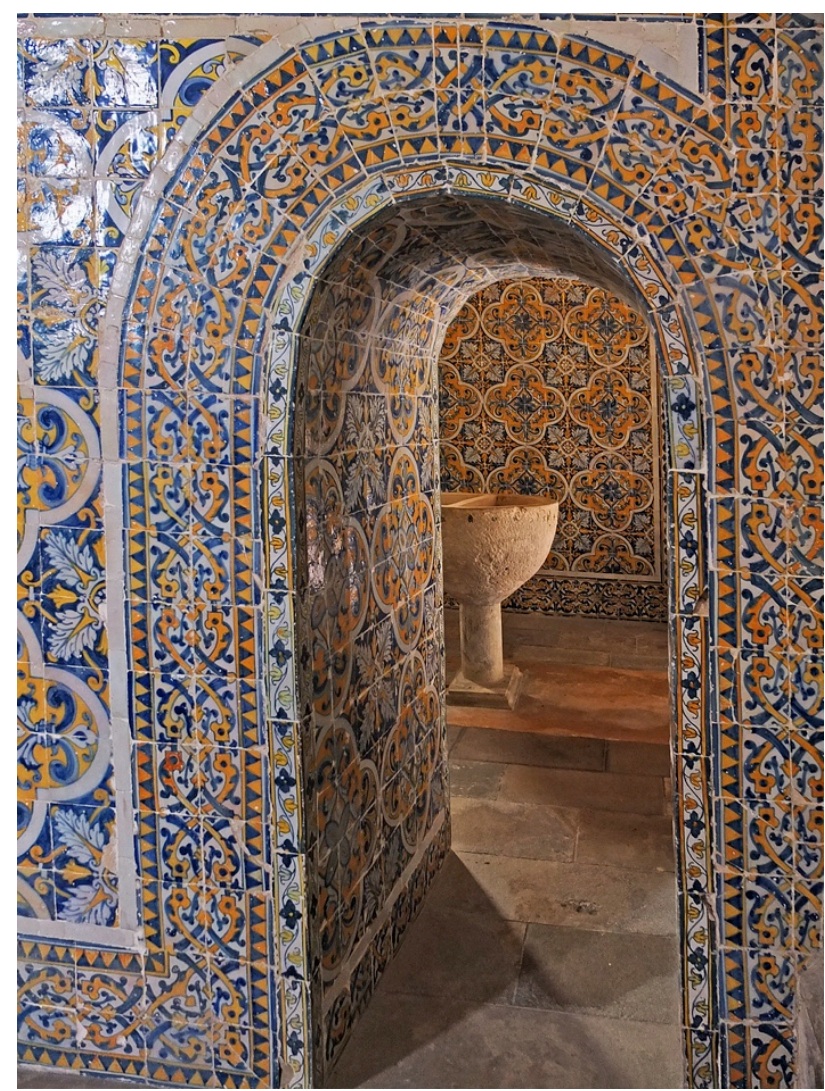

Figure 4. Almoster, Church of the Convent of Almoster, $17^{\text {th }}$ century. Photo by Jorge Guerra Maio

At the turn of the $16^{\text {th }}$ century, Hispano-Moresque patterns with geometric motifs and lacerias dominated tile production, initially imported from Castile, but the research has focused mainly on the monuments in which they are applied. With the maiolica technique, patterns became more varied, largely produced during the $17^{\text {th }}$ century (figure 4 ). This period is characterized by a great diversity of models and applications (Pais 2012; Teixeira 2014), which have been analysed with the aid of the cataloguing method proposed by Santos Simões (Simões 1971) and developed later by other researchers. After the growing imposition of blue and white painting, with many models reduced to this chromatic palette, the second half of the $18^{\text {th }}$ century witnessed the rise of the so-called "Pombaline patterns". These carefully designed decorations favoured the effects of light and shadow (Pina et al. 2006; Santos 2013).

However, it was only in the 1840 s that tile patterns made their return, this time not in interior decorations but in urban façades, transforming the landscape of several towns and cities (figure 5). This period has motivated, in recent years, several studies about specific cities and regions, as well as monographs and theses (Almasqué et al. 1989; Amorim 1996; Ferreira 2009; Pires 2012; Silva 2015; Santos 2016), studies about factories (Mimoso et al., 2015, Queiroz 2016, Mimoso 2017), or specific sections within wider-ranging works (Domingues 2009).

The use of azulejos in urban façades continued until the early $20^{\text {th }}$ century, and was later recovered by artists and architects who, from the 1950s onwards, started theorizing about the subject (Loureiro 1962) and creating new patterns and decorations. Today, several artists, designers and architects go on using patterned tiles, exploring their limits and questioning the traditional definition of pattern.

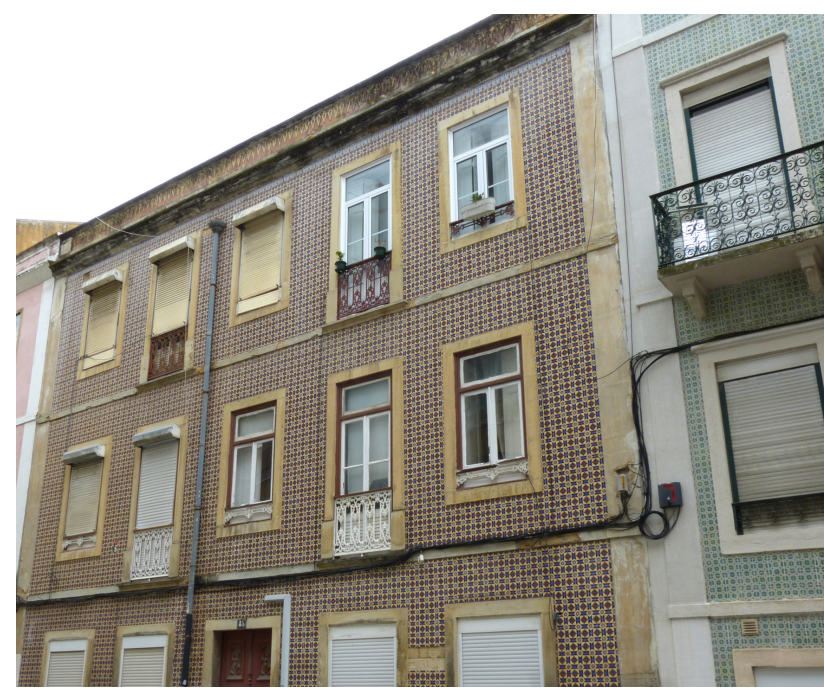

Figure 5. Lisbon, Cidade da Horta Street, n. 45,

pattern P-19-00062. Photo by Az Infinitum / Rute Ventura

As shown by this quick overview, most studies follow specific approaches, lacking an overall perspective. Instead of focusing on a truly representative sample, they study a few isolated examples, incapable of generating solid conclusions. The project Cataloguing Portuguese Patterned Azulejos (9) was launched in 2011 to address this problem. It is part of $A z$ Infinitum and aims to make available a tool for cataloguing patterns and frames, and for cross-referencing this information with an inventory of tile coverings still found in their original locations.

The methodology that was used builds on the work of João Miguel dos Santos Simões, who, in the second half of the $20^{\text {th }}$ century, carried out a large inventory and stressed the importance of this approach for the systematic and accurate study of Portuguese tiles (Simões, 1971). Over the last years, the team has catalogued tiles from the $16^{\text {th }}$ to the $20^{\text {th }}$ centuries, and the resulting scientific output attests to the validity and relevance of the project (Pais et al., 2011; Carvalho 2012;

(9) It was launched by the same promoters - the Azulejo Research Network, in partnership with the National Azulejo Museum and the company Sistemas do Futuro. 
Carvalho et al. 2012a; Carvalho et al. 2012b; Carvalho et al. 2013; Silva 2015; Carvalho, 2016).

By applying the technique of genetic printing or DNA profiling to tile decorations, this data structure aims to set up unique profiles for each tile pattern (encompassing different periods of the history of Portuguese tile decorations), by cross-referencing different markers. Once each profile has been created, it will allow users to retrace the "life path" of each pattern (wherever it has been applied), as well as its origins and affinities with other patterns. This procedure will help unveil a wide web of interconnections, highly relevant not only for the history of the azulejo, but also for Art History in general. Moreover, this will enable the identification and mapping of patterned tiles still found in situ.

The creation of profiles will thus lead to the development of a broad spectrum of analytical readings, comprising the following tasks: to establish precise manufacturing and application chronologies, as well as to obtain more accurate proposals regarding the time span of the different patterns; to identify the authors and reconsider the manufacturing process, by effectively identifying the different potteries and factories, and by offering a renewed perspective on their historical evolution; to distinguish "families" of motifs, both in specific epochs and in a broader context, comparing patterns from different periods in order to identify the recurrence of certain motifs and compositional schemes; to analyse the prevalence of certain patterns over time, in light of different cultural contexts; to reconsider and remap the colouring of the different patterns (the use of certain colours in the outlines and the filling of motifs is essential for establishing a work's chronology); to discuss how the scale, design and application of patterns have been understood over long periods of time; to document the diversity of patterns; to identify recurring combinations of patterns and frames; to identify external influences and sources of inspiration; to create maps based on the patterns, chronologies, places of production and colours.

The profiles can therefore be based on the objective features of each tile pattern, and complemented by other markers, determined by further research. The features in question are the following: the formal characteristics (module, number of tiles); the description, with a controlled vocabulary, of the main visual attributes, including the decorative motifs (using Iconclass), their degree of importance within the composition and the type of drawing, colouring, and technique. The information to be determined by further research is the following: the designation by which the pattern is known (with historiographical variables); the identification (documented or attributed) of the painter, pottery or factory; the exact dates of production or application (based on archival sources, pattern books, sales catalogues, promotional documents, etc.); documentation on the sources of inspiration (also based on pattern books, architectural treatises, etc.); the identification of links between patterns, and so on. One of the most relevant tasks is the comparison between every design or pattern with related patterned tiles and other sources of inspiration (e.g. books on ornaments, design journals, etc.). It was due to the dialectical interplay between different external factors, reflecting a global history of cultural exchange, and to the ability to interpret them at a local level, that the azulejo took shape and came to acquire its "original", Portuguese features. Some of these influences - from Spain, France, Belgium, the Netherlands, the United Kingdom, Italy, Germany, and even from the Arabic world - have already been studied, but a deeper and systematic research is still needed, to identify the links between the Portuguese and the European productions.

Contrary to other projects that simply photograph or digitize patterned tiles, the cataloguing work enabled by Az Infinitum focuses on research and aims to generate new knowledge. Drawing on a vast amount of information, it puts in place a methodology that is able to confirm (or not) the ideas anticipated by art historians and to substantiate others, through systematisation and data visualisation.

The data structure includes the following information groups: pattern number, module, description, classification, visual rhythm, chronology, authorship, iconography, technique, materials, colours, cataloguing, related patterns, in situ coverings, references, images. Many of the groups relate to other modules within the system, which constitute thereby important references for further systematisation. It is worth pointing out, very briefly, that in the case of tile patterns, just like in that of figurative decorations, the description and indexation of the different motifs are also carried out with Iconclass. But here the problems have been much greater, since the terms used by the system are not detailed enough for our level of description. Nonetheless, the need to come up with better terms to describe the motifs featured in each pattern enables the latter to be added to Iconclass, thereby enriching the system with new technical terms and contributing to $\mathrm{Az}$ Infinitum's growing international significance. Moreover, the project also deals with the issue of symmetry, in connection with the research carried out by a group of mathematicians.

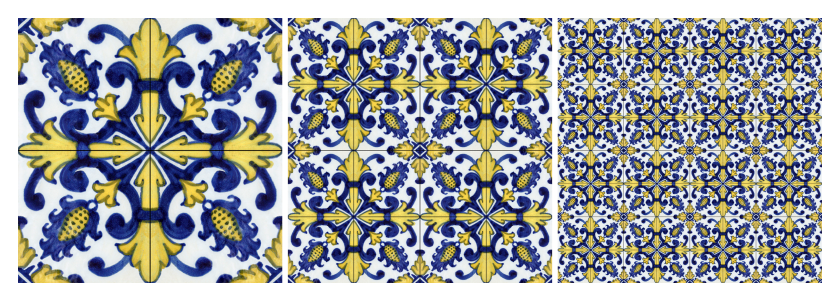

Figure 6. Pattern P-17-00101

Photo by Az Infinitum / Inês Aguiar

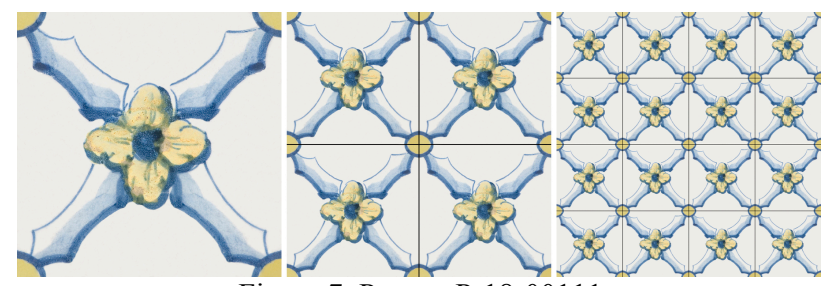

Figure 7. Pattern P-18-00111

Photo by Az Infinitum / Inês Aguiar

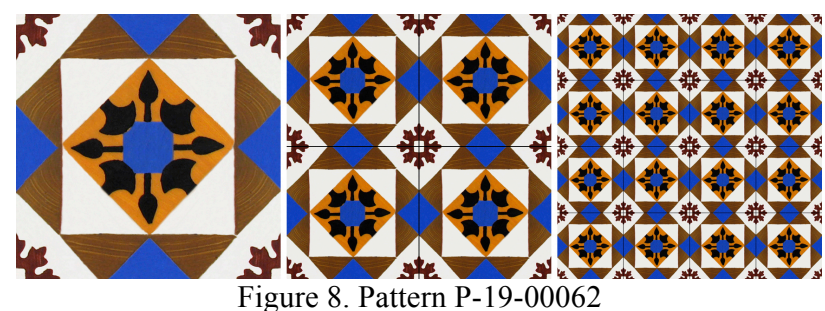

Photo by Az Infinitum / Inês Aguiar

However, the greatest innovation in this field is the digital treatment of images. In fact, an important part of the cataloguing procedure is the visual analysis of the patterns' characteristics and visual rhythms. The digital images created by photographers are based on photographs taken in situ, 
usually with very different lightings, angles and resolution levels. And these differences are made even worse by the works' different degrees of preservation. Accordingly, the digital images are based on the photographs with the most complete tile(s). Photographers resort to an editing process that eliminates impurities and rebuilds the damaged parts, while trying to preserve the plasticity of the tiles themselves. Subsequently, they produce a series of flattened digital reconstructions of the pattern, in order to recreate its application - from a small repeating motif (module) to the simulation of its full-scale effect, applied on a large surface (figures 6-8) (10). This structure seeks to create similar conditions across all patterns and frames, and thus to improve the analysis of their specific features, without losing sight of the specific features of each period.

By recreating patterns - from a single module all the way to a full-scale application - these digital surrogates facilitate comparative analysis and promote the development of visual comparison tools - such as the one currently being developed by Catarina Pinheiro, Mathilda Larsson and David Ortega (11). Generally speaking, any person can photograph a patterned tile, upload it and have it identified with the aid of the information compiled in Az Infinitum's records. These will indicate when the pattern was produced, by which factory, where else it was used and whether there are identical or related examples. Users can also ask the community to collaborate by reviewing and correcting the information (highlighting aspects that might otherwise remain unknown), as well as communicate the location of new coverings, denounce cases of neglect and degradation, etc.

\section{FINAL SUMMARY}

The images are the element binding the whole structure together. In view of the major role they play in this context, it has decided some time ago to hire professional photographers to record the different coverings, digitize the old images used as documents and recreate patterns, made available as visual cataloguing instruments. The use of high-quality images allows not only for a more effective documentation of this heritage, through the creation of updated documents turned towards the future, but also for the recourse to tools capable of exploring their potentialities, such as the apps provided by the International Image Interoperability Framework (IIIF) (https://iiif.io), which it is hoped to implement shortly. Apart from the tools for high-resolution zoomable images, the app Mirador "enables the comparison of multiple images from multiple repositories", creating a workspace that is particularly suited to the comparison between the figurative compositions and the engravings that inspired the painters. Knowledge of these engravings is essential for contextualizing the decorations.

On the other hand, 3D reconstructions and similar documentation processes have been carefully analysed, through the assessment of their cost/benefit value and their contribution to the project in terms of actual knowledge. For now, however, $A z$ Infinitum resorts to these tools mainly to reconstruct

(10) However, the recreations of Mudejar patterned tiles allow for two modes of visualization: a flattened version and a second one which simulates the embossed surfaces obtained through the different ceramic techniques: cuerda seca, arista and relief. (11) Moreover, a REST-style application programming interface (API) for developers will be provide, to be used in their products and services. decorations that have already disappeared. At least one case is now being tested, but we are still awaiting the final results.

The study of Portuguese tile decorations requires the recognition of their specificity and of their place within the field of Art History and other scientific fields, as well as an increasingly multidisciplinary approach. It also requires the further internationalization of this kind of research. Indeed, azulejos are part of a visual matrix that is also present beyond European borders, due to the long practice of drawing inspiration from models that were disseminated through engravings, but also tapestries, textiles, illuminations, goldsmithery, etc. On the other hand, by assuming Art History as its main research field, following an inventory tradition that dates back to the last quarter of the $19^{\text {th }}$ century, Az Infinitum places itself in what might be called today the field of Digital Art History. After all, its main goals include researching new documentation and data visualization methods, as well as engaging with computer vision and automatic image comparison, among other emerging research tools.

In short, $A z$ Infinitum aims to go on adopting a collaborative approach, together with other institutions relevant for the study of tile decorations, or with specific responsibilities in this field. The goal is to produce inventories in accordance with clear and verifiable strategies, and to create the necessary conditions for the actual sharing of data. Moreover, this exchange is not to be confined to tile decorations. It must be extended to other research areas, such as the study of engravings and iconography, thereby enabling researchers to benefit from larger structures and wider-ranging projects, on an open and cooperative basis. Above all, however, the aim is to provide information on a heritage whose importance is widely recognized and allow it to be used for different purposes.

\section{ACKNOWLEDGEMENTS}

This study was funded by Fundação para a Ciência e Tecnologia (FCT-Portugal) with a postdoctoral grant (SFRH/BPD/84867/2012) supported by the European Social Fund through the Human Capital Operational Programme (HCOP), and by national funds from the Ministry of Science, Technology and Higher Education.

\section{REFERENCES}

Almasqué, Isabel, e António Barros Veloso. 1989. Azulejos de fachada em Lisboa. Lisboa: CML/Banco Totta \& Açores.

Amorim, S. A. 1996. Azulejaria de fachada na Póvoa de Varzim: 1850-1950. Author's Ed.

Baca, M., Harpring, P. 2016. Categories for the Description of Works of Art. J. Paul Getty Trust and College Art Association. http://www.getty.edu/research/publications/electronic_publicati ons/cdwa (20 January 2019).

Baca, M., Harpring, P., Lanzi, E., McRae, L., Whiteside, A.B. 2006. Cataloging Cultural Objects: A Guide to Describing Cultural Works and Their Images. The Visual Resources Association.

Calado, L.F., Leite, J.P., Pereira, P. 2003. Património integrado ou a alma dos monumentos. Património estudos, (4), pp. 5-15. 
Carvalho, R.S., 2012. A pintura do azulejo em Portugal [16751725]: autorias e biografias - um novo paradigma. $\mathrm{PhD}$ Thesis, Lisboa: Universidade de Lisboa http://repositorio.ul.pt/handle/10451/6527 (21 January 2019).

Carvalho, R.S., 2016. Cataloguing Baroque azulejo frames. A project in progress. AzLab\#14 Azulejos and Frames. Proceedings (special issue of ARTisON), (2), pp. 33-41 http://artison.letras.ulisboa.pt/index.php/ao/article/view/41 January 2019).

Carvalho, R.S., 2018. Az Infinitum - Sistema de Referência e Indexação de Azulejo. ARTIS - Revista de História da Arte e Ciências do Património, 2(6), pp. 84-91.

Carvalho, R.S, Pais, A., Almeida, A., Aguiar, I., Pires I., Marinho, L., Nóbrega, P., 2012a. 17th century patterned azulejos from the Monastery of Santa Marta, in Lisbon. Journal of Science and Technology of the Arts, 4(1) doi:10.7559/citarj.v4i1.66.

Carvalho, R.S, Pais, A., Almeida, A., Aguiar, I., Pires I., Marinho, L., Nóbrega, P., 2012b. 17th Patterned Azulejos from Portugal. Glazed Expressions - The Magazine of TACS, the Tiles and Architectural Ceramics Society, (70), pp. 16-18.

Carvalho, R.S, Pais, A., Figueiredo, A.P., 2014/2018. Guia de Inventário de Azulejo in situ.

http://redeazulejo.fl.ul.pt/multimedia/File/guia_inventario_v1.p df (20 January 2019).

Carvalho, R.S., Queiroz F., Pais, A., Almeida, A., Aguiar, I., Pires I., Marinho, L., Nóbrega, P. 2013. Do azulejo manual ao azulejo industrial: a presença da padronagem portuguesa tradicional na produção da Fábrica do Carvalhinho. Cadernos de História da Arte, (1), pp. 136-155.

Carvalho, R.S., Silva, L.M.. 2016. Azulejo em/in Braga -O Largo Tempo do Barroco / The Baroque Period. Vila Nova de Famalicão: Centro Atlântico.

Core Data Index to Historic Buildings and Monuments of the Architectural Heritage. http://archives.icom.museum/objectid/heritage/core.html (17 January 2019).

Core Data Standard for Archaeological Sites and Monuments. http://archives.icom.museum/objectid/heritage/int.html (17 January 2019).

Domingues, A.M.P., 2009. A ornamentação cerâmica na arquitectura do Romantismo em Portugal. PhD Thesis, Porto: Faculdade de Letras da Universidade do Porto.

Ferreira, L.M., 2009. El azulejo en la arquitectura de la ciudad de Oporto (1850-1920). Caracterización e Intervención / O azulejo na arquitectura da cidade do Porto (1850-1920). Caracterização e intervenção. $\mathrm{PhD}$ Thesis, Facultad de Bellas Artes da Universidad del País Vascore.

International Guidelines for Museum Object Information: the CIDOC Information Categories.

https://icom.museum/en/ressource/international-guidelines-formuseum-object-information-the-cidoc-information-categories/ (18 January 2019).
Loureiro, J. C., 1962. O azulejo. Possibilidades da sua reintegração na arquitectura portuguesa. Porto.

Myers, D., Dalgity, A., Avramides, I.. 2016. The Arches heritage inventory and management system: a platform for the heritage field. Journal of Cultural Heritage Management and Sustainable Development, 6 (2), pp. 213-224. https://doi.org/10.1108/JCHMSD-02-2016-0010 (10 January 2019)

Mimoso, J.M., 2017. Lisboa. Azulejaria de fachada / Tiled façades. Azulejos - Maravilhas de Portugal / Wonders of Portugal. Vila Nova de Famalicão, Centro Atlântico, pp.187193.

Mimoso, J.M., Pais, A.N., Campelo J., Esteves, L., 2015. An unlikely catalogue of the production of azulejos byFábrica Roseira of Lisbon circa 1870. In: GlazeArch2015 International Conference Glazed Ceramics in Architectural Heritage, Lisboa, LNEC, pp. 81-90.

Pais, A.N., 2012. "Padrões (ainda) imprecisos. A azulejaria de repetição no século XVII". In: Um gosto português o uso do azulejo no século XVII, Lisboa, Athena, pp. 83-95.

Pais, A., Carvalho, R.S, Almeida, A., Aguiar, I., Pires I., Marinho, L., Nóbrega, P., 2011. Azulejos de padrão - uma proposta de catalogação. INVENIRE - Revista de Bens Culturais da Igreja, (3), pp. 12-15.

Pinho, J. B., Jacinto, T., 2006. O azulejo de padrão pombalino: tipologias e características. Atlântida (LI), pp. 33-48.

Pires, I., 2012. Fachadas azulejadas na margem sul do Tejo Barreiro (1850-1925). Master's dissertation, Lisboa: Faculdade de Letras, Universidade de Lisboa.

http://hdl.handle.net/10451/9952 (12 January 2019).

Queiroz, F., 2016. Os catálogos da Fábrica das Devesas. Lisboa, Chiado Editora.

Santos, C.E.F., 2016. Artes Decorativas nas Fachadas da Arquitectura Bairradina. Mealhada: Câmara Municipal da Mealhada.

Santos, D.G., 2013. Azulejaria de fabrico coimbrão (16991801): artifices e artistas, cronologia, iconografia. PhD Tehsis, Porto, Faculdade de Letras da Universidade do Porto https://repositorio-aberto.up.pt/handle/10216/72785 (12 January 2019)

Silva, L.M., 2015. I Love Braga - Janelas, Batentes e Azulejos. Vila Nova de Famalicão, Centro Atlântico.

Simões, J.M.S., 1971. Azulejaria em Portugal no século XVII. Lisboa, Fundação Calouste Gulbenkian.

Teixeira, C.V. 2014. Du potier au peintre d'azulejos: la genèse d'un art au temps des Philippes (1556-1668). Regards croisés sur les ateliers de Séville, Talavera de la Reina et Lisbonne. $\mathrm{PhD}$ Thesis, Paris, Université Paris-Sorbonne 4.

Updated to docx January2019 